\title{
Hypercholesterolemia Tunes Hematopoietic Stem/Progenitor Cells for Inflammation and Atherosclerosis
}

\author{
Xiaojuan Ma ${ }^{1,2}$ and Yingmei Feng ${ }^{1,2, *}$ \\ 1 Beijing Key Laboratory of Diabetes Prevention and Research, Lu He Hospital, Capital Medical University, \\ Beijing 101149, China; maxiaojuans@163.com \\ 2 Department of Endocrinology, Lu He Hospital, Capital Medical University, Beijing 101149, China \\ * Correspondence: yingmeif13@sina.com; Tel.: +86-10-6954-3901; Fax: +86-10-6953-1069
}

Academic Editor: Shaker A. Mousa

Received: 2 June 2016; Accepted: 14 July 2016; Published: 19 July 2016

\begin{abstract}
As the pathological basis of cardiovascular disease (CVD), atherosclerosis is featured as a chronic inflammation. Hypercholesterolemia is an independent risk factor for CVD. Accumulated studies have shown that hypercholesterolemia is associated with myeloid cell expansion, which stimulates innate and adaptive immune responses, strengthens inflammation, and accelerates atherosclerosis progression. Hematopoietic stem/progenitor cells (HSPC) in bone marrow (BM) expresses a panel of lipoprotein receptors to control cholesterol homeostasis. Deficiency of these receptors abrogates cellular cholesterol efflux, resulting in HSPC proliferation and differentiation in hypercholesterolemic mice. Reduction of the cholesterol level in the lipid rafts by infusion of reconstituted high-density lipoprotein (HDL) or its major apolipoprotein, apoA-I, reverses hypercholesterolemia-induced HSPC expansion. Apart from impaired cholesterol metabolism, inhibition of reactive oxygen species production suppresses HSPC activation and leukocytosis. These data indicate that the mechanisms underlying the effects of hypercholesterolemia on HSPC proliferation and differentiation could be multifaceted. Furthermore, dyslipidemia also regulates HSPC-neighboring cells, resulting in HSPC mobilization. In the article, we review how hypercholesterolemia evokes HSPC activation and mobilization directly or via its modification of BM microenvironment. We hope this review will bring light to finding key molecules to control HSPC expansion, inflammation, and atherosclerosis for the treatment of CVD.
\end{abstract}

Keywords: hematopoietic stem/progenitor cells; hypercholesterolemia; reactive oxygen species; cholesterol efflux; atherosclerosis

\section{Preface}

Cardiovascular disease (CVD) has remained the number one cause of mortality in the world for decades. The pathological basis of CVD is atherosclerosis, which is featured as atherosclerotic plaques in the artery wall leading to the restriction of blood flow. From the pathophysiological aspect, atherosclerosis initiates from disrupted endothelium which allows circulating apolipoprotein B (apoB)-containing lipoproteins to penetrate and accumulate in subendothelium where they further undergo chemical modification. Modified lipoproteins, particularly, oxidized low-density lipoprotein (LDLs), promote the proinflammatory phenotype of endothelial cells for increased vascular cell adhesion protein 1 (VCAM1) and intercellular adhesion molecule 1 (ICAM1) expression and proinflammatory cytokine production, all of which attract circulating white blood cells homing to the lesion site [1-4]. Following infiltration into the lesion site, monocytes, dendritic cells and $\mathrm{T}$ lymphocytes uptake fat and cholesterol to become foam cells that aggravate the inflammation cascade [5-7]. In the meantime, medical smooth muscle are activated for proliferation and migration 
to participate plaque formation and progression [8]. As a result, atherosclerotic plaque is formed with cellular components, such as white blood cells and smooth muscle cells, as well as acellular components, including cholesterol and collagen, leading to the restriction of blood flow.

Compelling evidence has demonstrated how risk factors, such as hypercholesterolemia, provoke inflammation and reinforce the initiation and progression of atherosclerosis. Interestingly, recent studies reported that hypercholesterolemia has an impact on hematopoietic stem/progenitor cells (HSPC) in the bone marrow (BM) niche to strengthen inflammation. In this article, we will explore how hypercholesterolemia orchestrates inflammatory cells, in particular, HSPC in BM in the pathogenesis of atherosclerosis.

\section{Hypercholesterolemia Facilitates Inflammation}

Physically, endothelial cells in arteries are exposed to unsteady flow because the velocity of blood waves during cardiac cycle. Endothelial cells sense the mechanic changes of blood flow and respond for adaptation, in which Krüppel-like factor 2 (KLF2) and endothelial nitric oxide synthase (eNOS) are fluid shear stress-responsive proteins and play crucial roles in the preservation of endothelium function [9]. However, in the regions close to bifurcation and curve of arteries, the endothelial phenotype is altered in response to the disturbed flow. They display a proinflammatory profile as featured by the activation of nuclear factor kappa B (NF-kB) [10,11], production of proinflammatory cytokines [12], and adhesion molecules [13,14], with reduced eNOS expression $[10,11,13,14]$. To be addressed, the sites with disturbed flow, also called "atherosusceptible sites" do not progress to significant inflammation and atherosclerosis until risk factors add onto it. In the text below, we focus on how hypercholesterolemia speeds up the development of atherosclerosis.

Indeed, myeloid cells, endothelial cells, and lymphocytes in atherosclerotic plaques are all affected by hypercholesterolemia. Numerous in vitro and in vivo mice studies have illustrated that excessive accumulation of intracellular cholesterol [15,16] and oxidized LDL [17] promote endothelial cell apoptosis and dysfunction. Although the molecular pathways might differ, elevated reactive oxygen species (ROS) production, with reduced nitric oxide level and bioavailability, are consistently involved in hypercholesterolemia-induced endothelial cell apoptosis $[15,18,19]$. Following endothelial cell apoptosis and dysfunction, a series of proinflammatory cytokines including tumor necrosis factor- $\alpha$ (TNF- $\alpha$ ), monocyte chemoattractant protein-1 (MCP-1), C-reactive protein and adhesion molecules such as VCAM1 and ICAM1 are induced, which trigger white blood cell recruitment toward activated endothelial cells [20-24].

Using the high-speed multichannel epifluorescence and 2-photon laser scanning microscopy (TPLSM), inflammatory cells that recruit to lesion site could be visualized in living apoE ${ }^{-/-}$mice after injection of fluorescently-labeled antibodies against monocytes, neutrophils, T lymphocytes or activated platelets, separately. This study elaborately demonstrated the timing and dynamics of different leukocyte subsets rolling to carotid bifurcation: (1) myeloid cells started to adhere to the carotid bifurcation after 10 days of high-fat diet (HFD); (2) the number of rolling neutrophils increased over time after two and six weeks of HFD, whereas monocytes number remained similar as both time points, but decreased after six weeks of HFD; and (3) T lymphocytes started rolling after six weeks of HFD. In addition, they found that activated platelets were adhered to the plaque via interaction of previously-tethered monocytes and neutrophils [25].

Following recruitment, neutrophils, monocytes, T lymphocytes, and platelets synergistically elicit inflammation and contribute substantially to atherosclerosis progression. Macrophages uptake lipoproteins and become foam cells in the plaque. As the hallmark of atherosclerotic plaque, foam cells are involved in all stages of atherosclerosis, from the initiation to progression of the plaque, to foam cell necrosis for plaque vulnerability and clinical features of atherosclerosis [26].

The activity of macrophages are regulated by neutrophils, T lymphocytes, and platelets. Physically, neutrophils are the first cells to home in on the infection site where they secrete granule proteins to clear microorganisms [27]. Depletion of neutrophils in $\mathrm{apoE}^{-/-}$mice on HFD results in reduced 
plaque size with decrease of monocyte/macrophage and dendritic cell number in the aortic lysate, implying the role of neutrophils in the guidance of monocyte and dendritic cell rolling to the lesion in the development of atherosclerosis [28]. Th1 cells could regulate macrophage activity by releasing inflammatory cytokines and activating of mast cells for IgE production $[29,30]$. The pathological roles of activated platelets in atherosclerosis are multidimensional. Platelets interact with leukocytes via receptor and ligand interaction [31-33]. Once platelets adhere to inflamed endothelial cells, these interactions facilitate leukocytes extravasation and infiltration into plaque. Moreover, platelets could regulate leukocyte activity for phagocytosis [34,35], generation of reactive oxygen species [36] and monocyte differentiation to macrophages [37].

Hypercholesterolemia also interplays with immunity in atherosclerosis. Toll-like receptors (TLRs) sense danger signals from pathogens and activate innate immune response for defense. Hypercholesterolemia activates TLR4 pathways, which suppresses the activity of Liver X Receptor (LXR) on it target genes, leading to impaired cholesterol efflux in macrophages [38,39]. Oxidative lipoproteins and ROS are both components to provoke innate immunity. Dendritic cells process and present epitopes/major histocompatibility complex (MHC) complexes of oxidized lipoproteins and heat shock protein 70 to naïve $\mathrm{T}$ cells, which stimulate effector $\mathrm{T}$ cell expansion and differentiation to participate inflammation [40,41].

For decades, there is a notion that leukocyte count predicts the incidence of cardiovascular events $[42,43]$. When looking for insight into differential white blood cell counts, circulating monocytes and neutrophils are positively associated with the occurrence and progression of CVD [44,45]. In line with these reports, hypercholesterolemia is tightly associated with monocytosis and neutrophila [46], whereas Statins inhibits hypercholesterolemia-induced leukocytosis and reduces the amount of atherogenic inflammatory cells [46]. Recently, other groups and we have elucidated that hypercholesterolemia promotes hematopoietic stem/progenitor cell (HSPC) proliferation and differentiation, resulting in leukocytosis and plaque progression in hypercholesterolemic apoE ${ }^{-/-}[47,48]$, $\mathrm{LDLr}^{-/-}[48,49]$, and SR-BI ${ }^{-/-}$[50] mice. Before we review how hypercholesterolemia modulates HSPC, we first briefly review the biology of HSPC.

\section{Hematopoietic Stem/Progenitor Cells (HSPC) Biology}

Despite controversy, hematopoiesis is comprised of two stages: "primitive hematopoiesis" in the yolk sac and "definitive hematopoiesis" in the aorta-gonad-mesonephros (AGM). Later on, hematopoiesis moves from AGM to the placenta, fetal liver at E11 and, finally, migrates to BM around birth [51-53]. Fetal liver and BM are both major sites of hematopoiesis, however, hematopoietic stem cells (HSC) in fetal liver are much more proliferative than HSC in BM, suggesting different metabolic demands. By performing RNA-Seq analysis of E14.5 fetal liver and BM HSC, Manesia et al. showed that HSC in fetal liver contained more mitochondria, which resulted in more ROS production [54]. Paradoxically, when residing in the hypoxic BM niche, 90\% HSCs remains quiescent with limited ROS production [54]. The quiescent HSCs are located in the endosteal niche, whereas dividing HSCs could be found in the perivascular niche. The hypoxic microenvironment is favorable for maintaining the self-renewal capacity and function of HSPC $[55,56]$.

Despite HSC being a small population, accounting for around $0.001 \%$ in total BM cells, they fulfill all of the characteristics of stem cells: the capacity of self-renewal in the generation of two HSCs and the ability of giving rise to all types of blood cells throughout life. The transition from quiescence to activation stages, and the mobilization of HSPC from BM to blood, are highly organized by intrinsic factors, extrinsic factors, receptors in HSPC, and surrounding cells in the niche. The stimuli for HSPC activation include chronic bacterial infection [57-59], psychosocial stress [60], injury, such as myocardial infarction [61], and hypercholesterolemia [47,48,50,62].

Except the intrinsic and extrinsic factors, HSPC activation and retention are modulated by the $\mathrm{BM}$ niche where HSPC are located. The supportive roles of BM niche on HSPC biology could be summarized below: (1) BM stromal cells and macrophages could produce hematopoietic cytokines such 
as thrombopoietin (TPO) [63], stem cell factor (c-Kit ligand) [64], and granulocyte colony-stimulating factor $[65,66]$ to support hematopoiesis; (2) endothelial cells preserve vasculature and interact with HSPC via the Tie2/angiopoietin-1 axis, angiopoietin-like proteins, and vascular endothelial growth factor (VEGF) signaling to assist HSC regeneration [67-70]; (3) retention of HSPC in the niche is mediated by its interaction with endothelial cells and stromal cells via integrins and $\mathrm{C}-\mathrm{X}-\mathrm{C}$ chemokine receptor type 4 (CXCR4)/stromal-derived-factor-1 (SDF-1) [71-73]. Thus, it is not surprising that disturbing the stability of BM niche could substantially change the fate of HSPC.

Among all the regulatory factors, ROS is the essential one for HSPC activation. It is not just a byproduct of oxidative stress, ROS accompanies HSPC to enter cell cycle for proliferation and differentiation [74-76]. Although it is hard to discriminate whether increased ROS production in HSPC is the cause or consequence of HSPC proliferation, inhibition of ROS production rescues HSPC exhaustion and senescence and regains the self-renewal capacity of HSPC [77].

Except circulating between BM and blood, HSPC are also found in the lung, liver, and spleen. It is not known when they arrive there and the origins of these HSPC during hematopoiesis. Nevertheless, these resident HSPC have been proven to differentiate into lymphocytes for immune surveillance [78].

\section{Hypercholesterolemia Induces HSPC Proliferation and Differentiation}

Like mature cells, intracellular cholesterol homeostasis in HSPC mainly replies on ATP-binding cassette transporter (ABCA1), the ATP-binding cassette sub-family G member 1(ABCG1), scavenger receptor type B-I (SR-BI), and apolipoprotein E (apoE) on the surface of these cells. In the absence of the lipoprotein receptors, diet-induced hypercholesterolemia leads to HSPC proliferation and differentiation in the BM niche, contributing substantially to leukocytosis in the peripheral blood $[47,50,62]$. When exploring mechanisms, Yves-Charvet et al. showed that deficiency of ABCA1 and ABCG1 promoted cholesterol accumulation in HSPC membrane, especially in the lipid rafts, which increased the expression of $\beta$ subunit of IL-3/granulocyte-macrophage colony-stimulating factor (GM-CSF) receptors and enhanced the proliferative responses to IL-3 and GM-CSF [62]. Likewise, Murphy et al. reported that impaired cholesterol efflux in HSPC failed to activate E3-ubiquitin ligase, resulting in increased IL-3R $\beta$ and M-CSF receptor expression in HSPC [47]. Ultimately, elevation of the IL3/IL3R axis, M-CSF, and GM-CSF signaling skewed HSPC differentiation for myeloid lineage production. Consistent with these findings, Gao, et al. observed the expansion of HSPC, common myeloid progenitors and granulocyte-macrophage progenitors in $\mathrm{BM}$ of SR-BI ${ }^{-/-}$mice on HFD [50]. Nonetheless, infusion of purified apoA-I or reconstituted HDL consistently reduced HSPC proliferation in these models, suggesting the importance of cholesterol homeostasis in controlling HSPC biology [47,50,62].

As described above, platelets play a key role in atherosclerosis. The biology of megakaryocyte progenitors (MKP) is tightly controlled by the turnover of TPO receptors, i.e., myeloproliferative leukemia protein (c-MPL) on MKP. In hypercholesterolemia, MKP in BM are challenged with increased cholesterol loading and impaired cholesterol efflux may develop in the absence of HDL receptor(s). Increased cellular cholesterol content increases c-MPL expression but decreases c-CBL (named after Casitas B-lineage Lymphoma) phosphorylation. The decreased c-CBL phosphorylation jeopardizes the negative feedback regulation of c-MPL by reduced ubiquitination and proteasomal degradation of c-MPL. Eventually, MKP are activated to proliferate in order to accelerate platelet production [79].

\section{Reactive Oxygen Species (ROS) Reduction Suppresses HSPC Expansion}

Is the impaired cholesterol efflux the solo mechanism for hypercholesterolemia-induced HSPC activation? The answer seems to be negative. When $\mathrm{SR}-\mathrm{BI}^{-/-}$and $\mathrm{LDLr}^{-/-}$apoA ${ }^{-/-}$mice fed on HFD received ROS inhibitor N-acetyl-L-cysteine (NAC), NAC reversed hypercholesterolemia-induced HSPC expansion, leukocytosis, and atherosclerosis progression in $\mathrm{SR}-\mathrm{BI}^{-/-}$and $\mathrm{LDLr}^{-/-}$apoA-I- $\mathrm{I}^{-/-}$ mice. Nevertheless, NAC treatment did not alter serum cholesterol level in the mice [50]. In parallel, hypercholesterolemia, including LDL stimulates endothelial cells and myeloid cells for ROS 
production [80], posing HSPC in an oxidative microenvironment to accelerate their expansion. These data collectively indicate that ROS could be an independent regulator for HSPC proliferation and differentiation.

\section{Hypercholesterolemia Modifies Bone Marrow (BM) Microenvironment for HSPC Mobilization}

In addition to HSPC proliferation in the BM niche, the frequency of circulating HSPC is also increased in hypercholesterolemia mice, indicating enhanced HSPC mobilization. HSPC are in communication with different cell types in BM microenvironment via integrins and the CXCR4/SDF axis, all of which maintain HSPC in the cavity of BM. How does hypercholesterolemia influence the BM microenvironment for HSPC mobilization? Histological analysis reveals that megakaryocytes form large clusters in close to BM sinusoidal vessels [81], implicating a modified situation between thrombolysis and hematopoietic equilibrium. Gomez et al. further showed that hypercholesterolemia distorted SDF gradient between blood and BM, leading to HSPC mobilization [81]. Consistent with this study, Westerterp et al. further delicately delineated the underlying mechanisms how hypercholesterolemia promoted HSPC mobilization in $\mathrm{ABCA1} 1^{-/-} \mathrm{ABCG} 1^{-/-}$mice [82]. They found that impaired cholesterol efflux increased extramedullary hematopoiesis with increased production of IL-23/IL-17/G-CSF in splenic macrophages and dendritic cells. They further demonstrated that hypercholesterolemia indirectly modified the structure of BM microenvironments by reduction of osteoblast numbers, especially, $\mathrm{N}$-Cadhern ${ }^{+}$osteoblasts and $\mathrm{Nestin}^{+}$mesenchymal stem cells. As the main source of SDF, the decreased number of osteoblasts and Nestin ${ }^{+}$mesenchymal stem cells resulted in reduced SDF production. Taken together, increased IL23/IL17/G-CSF production in the peripheral blood and reduced SDF in BM synergistically foster HSPC mobilization.

\section{Hypercholesterolemia Potentiates HSPC Homing to Lesion Site}

So far, a strong link has been verified between hypercholesterolemia, HSPC expansion, inflammation and atherosclerosis. Although HSPC reside in the BM niche, a minority of HSPC are trafficking among BM and blood and could home to tissues where they become resident cells for immune defense $[78,83]$. Therefore, questions arose: could BM-derived HSPC directly participate atherosclerosis? Whether and how does hypercholesterolemia impact on HSPC function?

To explore the questions, Wang et al. screened integrins' expression on HSPC in $\mathrm{LDLr}^{-/-}$mice fed on chow or HFD. By flow cytometry, increased integrin $\beta_{2}$ expression was detected in HSPC of hypercholesterolemia $\mathrm{LDLr}^{-/-}$mice compared with controls [84]. When fluorescently-labeled lineage-negative cells were injected to the recipients baring a complete ligation in the right carotid artery, Lineage-Sca- $1^{+} \mathrm{CKit}^{+} \mathrm{HSPC}$ were identified homing to the injury site by flow cytometry. The nature of homed HSPC was further confirmed by their potential in BM reconstitution upon injection into lethally irradiated recipients. Due to the technical limitation, it is not feasible to trace the fate of homed HSPC in the ligated artery. However, one assumption could be drawn that hypercholesterolemia could modify HSPC motility and enhance recruitment activity to contribute to atherosclerosis.

\section{High-Density Lipoprotein and HSPC}

Distinct from very low-density lipoprotein (VLDL) and LDL, high-density lipoproteins (HDLs) and its major apolipoprotein A-I (apoA-I) are inversely related to the risk of CVD [85]. The mechanisms underlying the beneficial effects of HDLs and apoA-I include reverse cholesterol transport, maintenance of endothelium integrity, and suppression of inflammation [86-89].

HDL-mediated cholesterol efflux serves as fundamental machinery to achieve cholesterol homeostasis in cells. HSPC are not the exception. In vitro, addition of HDLs to cultured Lineage $-\mathrm{Sca}-1^{+} \mathrm{CKit}{ }^{+}$HSPC retains the quiescence status and prohibits LDL-induced HSPC proliferation and differentiation, therefore, limiting the production of atherogenic myeloid cells $[48,90]$ (Figure 1 ). In vivo, infusion of reconstitute HDL or purified apoA-I abolishes hypercholesterolemia-induced HSPC expansion and differentiation or MKP proliferation and, thus, suppresses inflammation and atherosclerosis 
progression $[47,50,79]$. Improved cholesterol metabolism or reduced ROS content is detected in these models. The detailed mechanisms how HDLs and apoA-I regulate HSPC is largely unknown. Neither is clear how HDLs orchestrate HSPC-neighboring cells in the BM niche for HSPC maintenance.
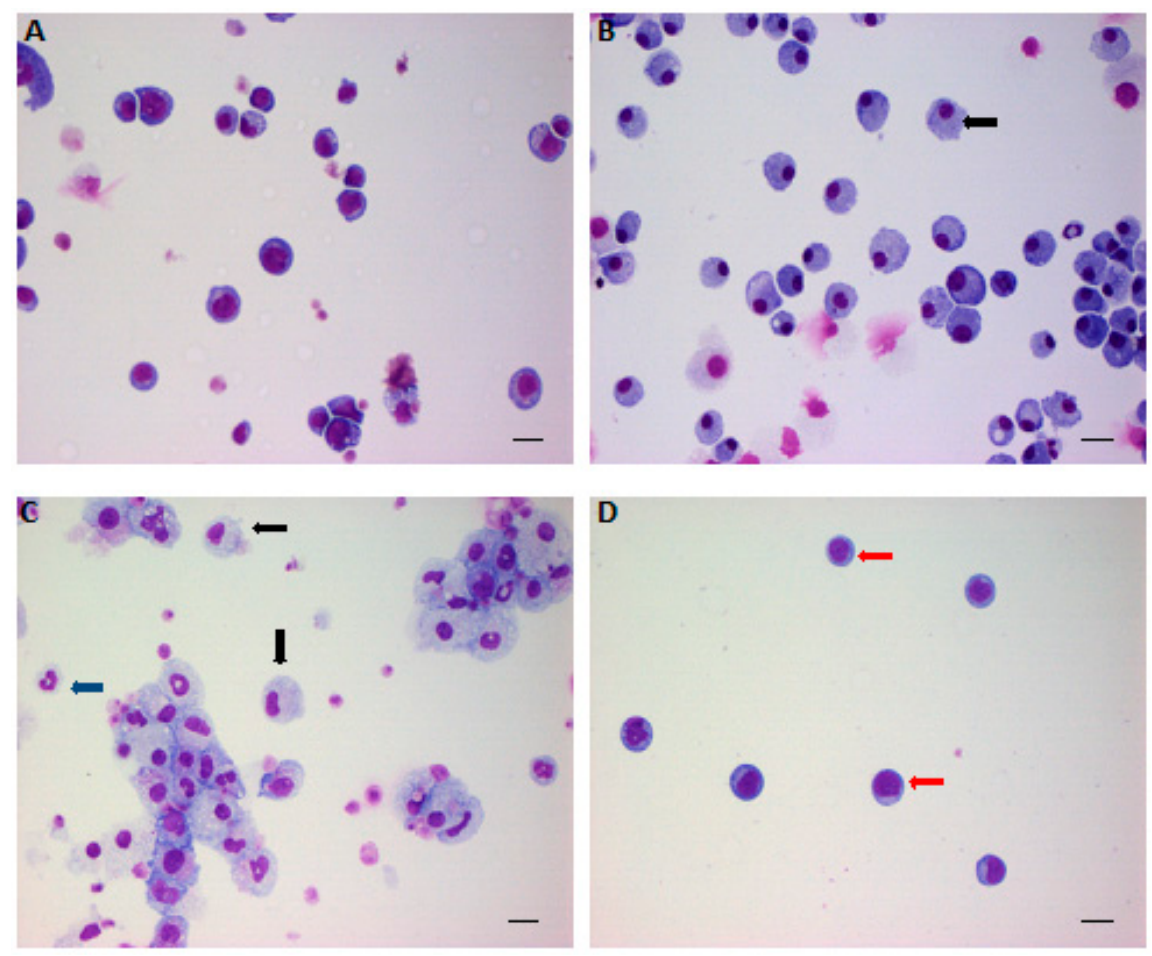

Figure 1. The effects of low-density lipoprotein (LDL) and high-density lipoprotein (HDL) on hematopoietic stem/progenitor cell (HSPC) expansion and differentiation. Lineage $\mathrm{Sca}^{-} \mathbf{1}^{+} \mathrm{CKit}^{+}$cells were sorted out by fluorescence-activated cell sorting (FACS) and cultured in serum-free medium in the presence of BSA (A); granulocyte-macrophage colony-stimulating factor (GM-CSF) (B); or LDL (C); and LDL plus HDL (D) for 14 days and then collected by cytospin for Giemsa staining. Red arrow indicates quiescent HSPC; black arrow indicates promonocytes; blue arrow indicates granulocytes. Scale bar: $20 \mu \mathrm{m}$. Adapted from Feng et al, PLoS ONE 2012.

\section{Hyperglycemia, Obesity, and Myelopoiesis}

Except hypercholesterolemia, skewed myeloid cell expansion is also observed in diabetic mice and obese subjects [91,92]. Studies of type 1 diabetic (T1D) mice uncovered that hyperglycemia stimulates neutrophils to produce S100A8/A9. Once released, S100A1/A9 acts on the receptor for advanced glycation endproducts (RAGE) on BM common myeloid progenitors (CMP) and macrophages to activate NF- $\mathrm{kB}$ transcription for M-CSF and GM-CSF production, both of which trigger CMP and granulocyte-macrophage progenitor (GMP) proliferation for myelopoiesis [93].

Adipose tissues are another source for S100A8/A9 production. In obese ob/ob mice, excessive visceral adipose tissues produce large amounts of S100A8/A9 that promotes Toll-like receptor 4 (TLR4)-Myeloid differentiation factor 88 (MyD88)signaling in adipose tissue macrophages for NACHT, LRR and PYD domains-containing protein 3 (NLRP3) inflammasome activation and IL-1 $\beta$ production. Through circulation, IL-1 $\beta$ reaches BM where it engages to IL-1R on CMP and GMP to drive myelopoiesis, leading to monocytosis and neutrophilia [94]. The intimate communication between adipose tissue macrophages and BM HSPC is also illustrated in wide-type mice fed on HFD in which MyD88 mediates HSPC proliferation for increased CMP and GMP, resulting in myelopoiesis. To be noted, different from hypercholesterolemia, the frequency of HSPC in BM of T1D mice or ob/ob mice is not altered [93,94]. It will be of great interest to explore why autonomous obesity and T1D affect CMP and GMP, but not HSPC. 


\section{Summary and Perspectives}

The intimate relationship between inflammation and atherosclerosis progression has been confirmed. Suppression of inflammation as an adjunct factor for risk factor, is being tested in clinical trials and the results will come out next year [95,96]. As an independent risk factor of CVD, hypercholesterolemia stimulates HSPC proliferation and differentiation in BM, enhances ROS production in HSPC, increases the pool of inflammatory cells in peripheral blood and, thus, aggravates atherosclerosis. The mechanisms underlying the impact of hypercholesterolemia on HSPC are depicted in Figure 2. Improved cholesterol homeostasis and inhibition of ROS production serve as two pillars in the suppression of HSPC expansion and inflammation in the setting of hypercholesterolemia. Stabilization of BM niche may assist HSPC quiescence status and inhibition of inflammatory cell production. Thus, there is a need to search for key regulators that retain HSPC quiescence and function for inflammatory control when combating hypercholesterolemia-induced atherosclerosis.

normocholesterolemia

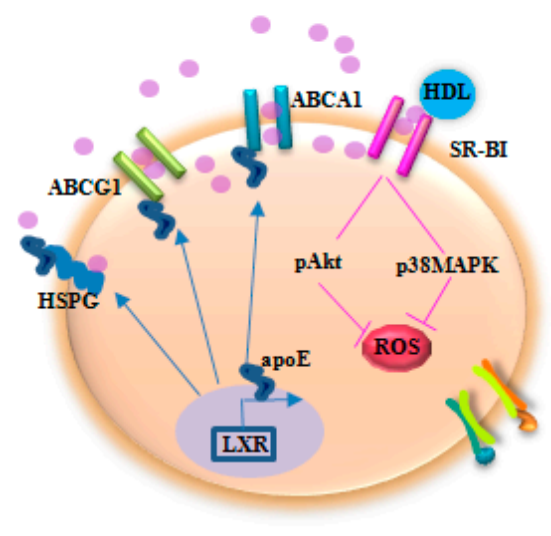

IL3
IL3 receptor

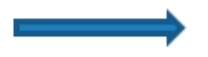

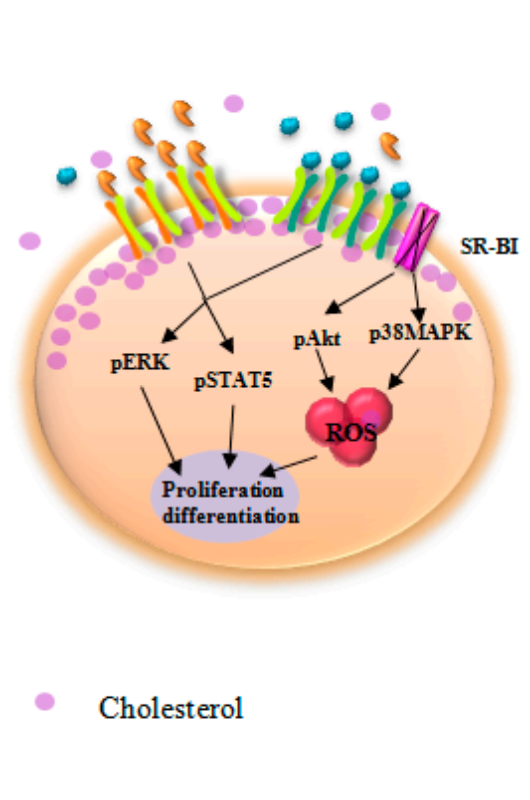

- Cholesterol

hypercholesterolemia

Figure 2. The mechanisms underlying the impact of hypercholesterolemia on HSPC. Under normocholesterolemia, ATP-binding cassette transporter (ABCA1), ATP-binding cassette sub-family G member 1(ABCG1), and scavenger receptor type B-I (SR-BI) facilitate cholesterol efflux. After secretion, apolipoprotein E (apoE) binds to heparin sulfate proteoglycans (HSPG) for cholesterol removal. Furthermore, apoE and apoE-containing HDL interact with ABCA1 and ABCG1 for reverse cholesterol transport. apoE, ABCA1, and ABCG1 expression are regulated by liver $\mathrm{X}$ receptor (LXR). HDL acts via SR-BI to control Akt and p38 mitogen-activated protein kinases (p38MAPK) phosphorylation and reactive oxygen species (ROS) production. As the net result, cholesterol homeostasis is maintained in HSPC. Deficiency of ABCA1, ABCG1, apoE, and SR-BI disrupts cholesterol efflux. Hypercholesterolemia accelerates impaired cholesterol efflux, leading to enriched cholesterol accumulation in the lipid raft. Thus, the expression of the common $\beta$ subunit of the IL-3/GM-CSF receptors is increased, resulting in elevated response to IL-3 and GM-CSF for HSPC proliferation. In parallel, SR-BI deficiency abrogates the regulation of HDL on ROS production. Therefore, HSPC are activated for proliferation and differentiation. The skewed HSPC differentiation to myeloid cells produces IL-3 and GM-CSF that further potentiate HSPC activation. pERK, phosphorylated extracellular signal-regulated kinase; pSTAT5, phosphorylated signal transducer and activator of transcription 5 . 
Conflicts of Interest: The authors declare no conflict of interest.

\section{References}

1. Milstone, D.S.; Ilyama, M.; Chen, M.; O’Donnell, P.; Davis, V.M.; Plutzky, J.; Brown, J.D.; Haldar, S.M.; Siu, A.; Lau, A.C.; et al. Differential role of an NF- $\mathrm{kB}$ transcriptional response element in endothelial versus intimal cell VCAM-1 expression. Circ. Res. 2015, 117, 166-177. [CrossRef] [PubMed]

2. Deng, W.; Deng, Y.; Deng, J.; Wang, D.X.; Zhang, T. Losartan attenuated lipopolysaccharide-induced lung injury by suppression of lectin-like oxidized low-density lipoprotein receptor-1. Int. J. Clin. Exp. Pathol. 2015, 8, 15670-15676. [PubMed]

3. Zhao, W.; Wu, C.; Chen, X. Cryptotanshinone inhibits oxidized LDL-induced adhesion molecule expression via ROS dependent NF-кB pathways. Cell Adh. Migr. 2015, 10, 1-11. [CrossRef] [PubMed]

4. $\quad$ Estruch, M.; Bancells, C.; Beloki, L.; Sanchez-Quesada, J.L.; Ordonez-Llanos, J.; Benitez, S. CD14 and TLR4 mediate cytokine release promoted by electronegative LDL in monocytes. Atherosclerosis 2013, 229, 356-362. [CrossRef] [PubMed]

5. Haka, A.S.; Singh, R.K.; Grosheva, I.; Hoffner, H.; Capetillo-Zarate, E.; Chin, H.F.; Anandasabapathy, N.; Maxfield, F.R. Monocyte-Derived Dendritic Cells Upregulate Extracellular Catabolism of Aggregated Low-Density Lipoprotein on Maturation, Leading to Foam Cell Formation. Arterioscler. Thromb. Vasc. Biol. 2015, 35, 2092-2103. [CrossRef] [PubMed]

6. Oliveira, R.T.; Silva, R.M.; Teo, F.H.; Mineiro, M.F.; Ferreira, M.C.; Altemani, A.; Mamoni, R.L.; Menezes, F.H.; Blotta, M.H. Detection of TCD4+ subsets in human carotid atheroma. Cytokine 2013, 62, 131-140. [CrossRef] [PubMed]

7. Cochain, C.; Zernecke, A. Macrophages and immune cells in atherosclerosis: Recent advances and novel concepts. Basic Res. Cardiol. 2015, 110, 34. [CrossRef] [PubMed]

8. Locher, R.; Brandes, R.P.; Vetter, W.; Barton, M. Native LDL induces proliferation of human vascular smooth muscle cells via redox-mediated activation of ERK $1 / 2$ mitogen-activated protein kinases. Hypertension 2002, 39, 645-650. [CrossRef] [PubMed]

9. Wang, W.; Ha, C.H.; Jhun, B.S.; Wong, C.; Jain, M.K.; Jin, Z.G. Fluid shear stress stimulates phosphorylation-dependent nuclear export of HDAC5 and mediates expression of KLF2 and eNOS. Blood 2010, 115, 2971-2979. [CrossRef] [PubMed]

10. Go, Y.M.; Son, D.J.; Park, H.; Orr, M.; Hao, L.; Takabe, W.; Kumar, S.; Kang, D.W.; Kim, C.W.; Jo, H.; et al. Disturbed flow enhances inflammatory signaling and atherogenesis by increasing thioredoxin-1 level in endothelial cell nuclei. PLoS ONE 2014, 9, e108346. [CrossRef] [PubMed]

11. Cuhlmann, S.; van der Heiden, K.; Saliba, D.; Tremoleda, J.L.; Khalil, M.; Zakkar, M.; Chaudhury, H.; Luong, L.A.; Mason, J.C.; Udalova, I.; et al. Disturbed blood flow induces RelA expression via c-Jun $\mathrm{N}$-terminal kinase 1: A novel mode of NF-KB regulation that promotes arterial inflammation. Circ. Res. 2011, 108, 950-959. [CrossRef] [PubMed]

12. Bao, X.; Lu, C.; Frangos, J.A. Temporal gradient in shear but not steady shear stress induces PDGF-A and MCP-1 expression in endothelial cells: Role of NO, NFkB, and egr-1. Arterioscler. Thromb. Vasc. Biol. 1999, 19, 996-1003. [CrossRef] [PubMed]

13. Won, D.; Zhu, S.N.; Chen, M.; Teichert, A.M.; Fish, J.E.; Matouk, C.C.; Bonert, M.; Ojha, M.; Marsden, P.A.; Cybulsky, M.I. Relative reduction of endothelial nitric-oxide synthase expression and transcription in atherosclerosis-prone regions of the mouse aorta and in an in vitro model of disturbed flow. Am. J. Pathol. 2007, 171, 1691-1704. [CrossRef] [PubMed]

14. Gimbrone, M.A., Jr.; Garcia-Cardena, G. Vascular endothelium, hemodynamics, and the pathobiology of atherosclerosis. Cardiovasc. Pathol. 2013, 22, 9-15. [CrossRef] [PubMed]

15. Westerterp, M.; Tsuchiya, K.; Tattersall, I.W.; Fotakis, P.; Bochem, A.E.; Molusky, M.M.; Ntonga, V.; Abramowicz, S.; Parks, J.S.; Welch, C.L.; et al. Deficiency of ATP-Binding Cassette Transporters A1 and G1 in Endothelial Cells Accelerates Atherosclerosis in Mice. Arterioscler. Thromb. Vasc. Biol. 2016, 112, 1456-1465.

16. Yu, C.; Luo, X.; Farhat, N.; Daneault, C.; Duquette, N.; Martel, C.; Lambert, J.; Thorin-Trescases, N.; Rosiers, C.D.; Thorin, E. Lack of angiopoietin-like-2 expression limits the metabolic stress induced by a high-fat diet and maintains endothelial function in mice. J. Am. Heart Assoc. 2014, 3, e001024. [CrossRef] [PubMed] 
17. Veas, C.; Jara, C.; Willis, N.D.; Perez-Contreras, K.; Gutierrez, N.; Toledo, J.; Fernandez, P.; Radojkovic, C.; Zuniga, F.A.; Escudero, C.; et al. Overexpression of LOXIN Protects Endothelial Progenitor Cells from Apoptosis Induced by Oxidized Low Density Lipoprotein. J. Cardiovasc. Pharmacol. 2016, 67, $326-335$. [CrossRef] [PubMed]

18. Chen, Z.; Wen, L.; Martin, M.; Hsu, C.Y.; Fang, L.; Lin, F.M.; Lin, T.Y.; Geary, M.J.; Geary, G.G.; Zhao, Y.; et al. Oxidative stress activates endothelial innate immunity via sterol regulatory element binding protein 2 (SREBP2) transactivation of microRNA-92a. Circulation 2015, 131, 805-814. [CrossRef] [PubMed]

19. Wang, X.; Wang, M.; Li, H.; Lan, X.; Liu, L.; Li, J.; Li, Y.; Li, J.; Yi, J.; Du, X.; et al. Upregulation of miR-497 induces hepatic insulin resistance in E3 rats with HFD-MetS by targeting insulin receptor. Mol. Cell. Endocrinol. 2015, 416, 57-69. [CrossRef] [PubMed]

20. N'Guessan, P.D.; Riediger, F.; Vardarova, K.; Scharf, S.; Eitel, J.; Opitz, B.; Slevogt, H.; Weichert, W.; Hocke, A.C.; Schmeck, B.; et al. Statins control oxidized LDL-mediated histone modifications and gene expression in cultured human endothelial cells. Arterioscler. Thromb. Vasc. Biol. 2009, 29, 380-386. [CrossRef] [PubMed]

21. Sanz-Rosa, D.; Oubina, M.P.; Cediel, E.; de Las Heras, N.; Vegazo, O.; Jimenez, J.; Lahera, V.; Cachofeiro, V. Effect of AT1 receptor antagonism on vascular and circulating inflammatory mediators in SHR: Role of NF-кB/IкB system. Am. J. Physiol. Heart Circ. Physiol. 2005, 288, H111-H115. [CrossRef] [PubMed]

22. Capers, Q., IV; Alexander, R.W.; Lou, P.; de Leon, H.; Wilcox, J.N.; Ishizaka, N.; Howard, A.B.; Taylor, W.R. Monocyte chemoattractant protein-1 expression in aortic tissues of hypertensive rats. Hypertension 1997, 30 , 1397-1402. [CrossRef] [PubMed]

23. Yamagata, K.; Miyashita, A.; Matsufuji, H.; Chino, M. Dietary flavonoid apigenin inhibits high glucose and tumor necrosis factor $\alpha$-induced adhesion molecule expression in human endothelial cells. J. Nutr. Biochem. 2010, 21, 116-124. [CrossRef] [PubMed]

24. Verma, S.; Wang, C.H.; Weisel, R.D.; Badiwala, M.V.; Li, S.H.; Fedak, P.W.; Li, R.K.; Mickle, D.A. Hyperglycemia potentiates the proatherogenic effects of C-reactive protein: Reversal with rosiglitazone. J. Mol. Cell. Cardiol. 2003, 35, 417-419. [CrossRef]

25. Chevre, R.; Gonzalez-Granado, J.M.; Megens, R.T.; Sreeramkumar, V.; Silvestre-Roig, C.; Molina-Sanchez, P.; Weber, C.; Soehnlein, O.; Hidalgo, A.; Andres, V. High-resolution imaging of intravascular atherogenic inflammation in live mice. Circ. Res. 2014, 114, 770-779. [CrossRef] [PubMed]

26. Tabas, I.; Bornfeldt, K.E. Macrophage Phenotype and Function in Different Stages of Atherosclerosis. Circ. Res. 2016, 118, 653-667. [CrossRef] [PubMed]

27. Zhang, X.; Majlessi, L.; Deriaud, E.; Leclerc, C.; Lo-Man, R. Coactivation of Syk kinase and MyD88 adaptor protein pathways by bacteria promotes regulatory properties of neutrophils. Immunity 2009, 31, 761-771. [CrossRef] [PubMed]

28. Drechsler, M.; Megens, R.T.; van Zandvoort, M.; Weber, C.; Soehnlein, O. Hyperlipidemia-triggered neutrophilia promotes early atherosclerosis. Circulation 2010, 122, 1837-1845. [CrossRef] [PubMed]

29. Conti, P.; Shaik-Dasthagirisaeb, Y. Atherosclerosis: A chronic inflammatory disease mediated by mast cells. Cent. Eur. J. Immunol. 2015, 40, 380-386. [CrossRef] [PubMed]

30. Kounis, N.G.; Hahalis, G. Serum IgE levels in coronary artery disease. Atherosclerosis 2016. [CrossRef] [PubMed]

31. Weber, C.; Springer, T.A. Neutrophil accumulation on activated, surface-adherent platelets in flow is mediated by interaction of Mac-1 with fibrinogen bound to $\alpha \mathrm{Ilb} \beta 3$ and stimulated by platelet-activating factor. J. Clin. Investig. 1997, 100, 2085-2093. [CrossRef] [PubMed]

32. Von Bruhl, M.L.; Stark, K.; Steinhart, A.; Chandraratne, S.; Konrad, I.; Lorenz, M.; Khandoga, A.; Tirniceriu, A.; Coletti, R.; Kollnberger, M.; et al. Monocytes, neutrophils, and platelets cooperate to initiate and propagate venous thrombosis in mice in vivo. J. Exp. Med. 2012, 209, 819-835. [CrossRef] [PubMed]

33. Etulain, J.; Martinod, K.; Wong, S.L.; Cifuni, S.M.; Schattner, M.; Wagner, D.D. P-selectin promotes neutrophil extracellular trap formation in mice. Blood 2015, 126, 242-246. [CrossRef] [PubMed]

34. Kockx, M.M.; Cromheeke, K.M.; Knaapen, M.W.; Bosmans, J.M.; de Meyer, G.R.; Herman, A.G.; Bult, H. Phagocytosis and macrophage activation associated with hemorrhagic microvessels in human atherosclerosis. Arterioscler. Thrombo. Vasc. Biol. 2003, 23, 440-446. [CrossRef] [PubMed]

35. Kral, J.B.; Schrottmaier, W.C.; Salzmann, M.; Assinger, A. Platelet Interaction with Innate Immune Cells. Transfus. Med. Hemother. 2016, 43, 78-88. [CrossRef] [PubMed] 
36. Pervushina, O.; Scheuerer, B.; Reiling, N.; Behnke, L.; Schroder, J.M.; Kasper, B.; Brandt, E.; Bulfone-Paus, S.; Petersen, F. Platelet factor 4/CXCL4 induces phagocytosis and the generation of reactive oxygen metabolites in mononuclear phagocytes independently of Gi protein activation or intracellular calcium transients. J. Immunol. 2004, 173, 2060-2067. [CrossRef] [PubMed]

37. Badrnya, S.; Schrottmaier, W.C.; Kral, J.B.; Yaiw, K.C.; Volf, I.; Schabbauer, G.; Soderberg-Naucler, C.; Assinger, A. Platelets mediate oxidized low-density lipoprotein-induced monocyte extravasation and foam cell formation. Arterioscler. Thromb. Vasc. Biol. 2014, 34, 571-580. [CrossRef] [PubMed]

38. Goldklang, M.; Golovatch, P.; Zelonina, T.; Trischler, J.; Rabinowitz, D.; Lemaitre, V.; D'Armiento, J. Activation of the TLR4 signaling pathway and abnormal cholesterol efflux lead to emphysema in apoE-deficient mice. Am. J. Physiol. Lung Cell. Mol. Phys. 2012, 302, L1200-L1208. [CrossRef] [PubMed]

39. Castrillo, A.; Joseph, S.B.; Vaidya, S.A.; Haberland, M.; Fogelman, A.M.; Cheng, G.; Tontonoz, P. Crosstalk between LXR and toll-like receptor signaling mediates bacterial and viral antagonism of cholesterol metabolism. Mol. Cell 2003, 12, 805-816. [CrossRef]

40. Hermansson, A.; Ketelhuth, D.F.; Strodthoff, D.; Wurm, M.; Hansson, E.M.; Nicoletti, A.; Paulsson-Berne, G.; Hansson, G.K. Inhibition of $\mathrm{T}$ cell response to native low-density lipoprotein reduces atherosclerosis. J. Exp. Med. 2010, 207, 1081-1093. [CrossRef] [PubMed]

41. Guisasola, M.C.; Dulin, E.; Almendral, J.; Garcia-Barreno, P. Reduction of heat shock protein antibody levels by statin therapy. Lipids 2009, 44, 317-324. [CrossRef] [PubMed]

42. Friedman, G.D.; Klatsky, A.L.; Siegelaub, A.B. The leukocyte count as a predictor of myocardial infarction. N. Engl. J. Med. 1974, 290, 1275-1278. [CrossRef] [PubMed]

43. Barron, H.V.; Cannon, C.P.; Murphy, S.A.; Braunwald, E.; Gibson, C.M. Association between white blood cell count, epicardial blood flow, myocardial perfusion, and clinical outcomes in the setting of acute myocardial infarction: A thrombolysis in myocardial infarction 10 substudy. Circulation 2000, 102, 2329-2334. [CrossRef] [PubMed]

44. Misialek, J.R.; Bekwelem, W.; Chen, L.Y.; Loehr, L.R.; Agarwal, S.K.; Soliman, E.Z.; Norby, F.L.; Alonso, A. Association of White Blood Cell Count and Differential with the Incidence of Atrial Fibrillation: The Atherosclerosis Risk in Communities (ARIC) Study. PLoS ONE 2015, 10, e0136219. [CrossRef] [PubMed]

45. Horne, B.D.; Anderson, J.L.; John, J.M.; Weaver, A.; Bair, T.L.; Jensen, K.R.; Renlund, D.G.; Muhlestein, J.B. Intermountain Heart Collaborative Study, Group, Which white blood cell subtypes predict increased cardiovascular risk? J. Am. Coll. Cardiol. 2005, 45, 1638-1643. [CrossRef] [PubMed]

46. Swirski, F.K.; Libby, P.; Aikawa, E.; Alcaide, P.; Luscinskas, F.W.; Weissleder, R.; Pittet, M.J. Ly-6Chi monocytes dominate hypercholesterolemia-associated monocytosis and give rise to macrophages in atheromata. J. Clin. Investig. 2007, 117, 195-205. [CrossRef] [PubMed]

47. Murphy, A.J.; Akhtari, M.; Tolani, S.; Pagler, T.; Bijl, N.; Kuo, C.L.; Wang, M.; Sanson, M.; Abramowicz, S.; Welch, C.; et al. apoE regulates hematopoietic stem cell proliferation, monocytosis, and monocyte accumulation in atherosclerotic lesions in mice. J. Clin. Investig. 2011, 121, 4138-4149. [CrossRef] [PubMed]

48. Feng, Y.; Schouteden, S.; Geenens, R.; van Duppen, V.; Herijgers, P.; Holvoet, P.; van Veldhoven, P.P.; Verfaillie, C.M. Hematopoietic stem/progenitor cell proliferation and differentiation is differentially regulated by high-density and low-density lipoproteins in mice. PLoS ONE 2012, 7, e47286. [CrossRef] [PubMed]

49. Seijkens, T.; Hoeksema, M.A.; Beckers, L.; Smeets, E.; Meiler, S.; Levels, J.; Tjwa, M.; de Winther, M.P.; Lutgens, E. Hypercholesterolemia-induced priming of hematopoietic stem and progenitor cells aggravates atherosclerosis. FASEB J. 2014, 28, 2202-2213. [CrossRef] [PubMed]

50. Gao, M.; Zhao, D.; Schouteden, S.; Sorci-Thomas, M.G.; van Veldhoven, P.P.; Eggermont, K.; Liu, G.; Verfaillie, C.M.; Feng, Y. Regulation of high-density lipoprotein on hematopoietic stem/progenitor cells in atherosclerosis requires scavenger receptor type BI expression. Arterioscler. Thromb. Vasc. Biol. 2014, 34, 1900-1909. [CrossRef] [PubMed]

51. Wang, L.D.; Wagers, A.J. Dynamic niches in the origination and differentiation of haematopoietic stem cells. Nat. Rev. Mol. Cell Biol. 2011, 12, 643-655. [CrossRef] [PubMed]

52. Gering, M.; Patient, R. Hedgehog signaling is required for adult blood stem cell formation in zebrafish embryos. Dev. Cell 2005, 8, 389-400. [CrossRef] [PubMed] 
53. Parmar, K.; Mauch, P.; Vergilio, J.A.; Sackstein, R.; Down, J.D. Distribution of hematopoietic stem cells in the bone marrow according to regional hypoxia. Proc. Natl. Acad. Sci. USA 2007, 104, 5431-5436. [CrossRef] [PubMed]

54. Manesia, J.K.; Xu, Z.; Broekaert, D.; Boon, R.; van Vliet, A.; Eelen, G.; Vanwelden, T.; Stegen, S.; van Gastel, N.; Pascual-Montano, A.; et al. Highly proliferative primitive fetal liver hematopoietic stem cells are fueled by oxidative metabolic pathways. Stem Cell Res. 2015, 15, 715-721. [CrossRef] [PubMed]

55. Khatri, R.; Krishnan, S.; Roy, S.; Chattopadhyay, S.; Kumar, V.; Mukhopadhyay, A. Reactive oxygen species limit the ability of bone marrow stromal cells to support hematopoietic reconstitution in aging mice. Stem Cells Dev. 2016, 25, 948-958. [CrossRef] [PubMed]

56. Chen, J.; Kang, J.G.; Keyvanfar, K.; Young, N.S.; Hwang, P.M. Long-term adaptation to hypoxia preserves hematopoietic stem cell Function. Exp. Hematol. 2016. [CrossRef] [PubMed]

57. Baldridge, M.T.; King, K.Y.; Boles, N.C.; Weksberg, D.C.; Goodell, M.A. Quiescent haematopoietic stem cells are activated by IFN- $\gamma$ in response to chronic infection. Nature 2010, 465, 793-797. [CrossRef] [PubMed]

58. Essers, M.A.; Offner, S.; Blanco-Bose, W.E.; Waibler, Z.; Kalinke, U.; Duchosal, M.A.; Trumpp, A. IFN $\alpha$ activates dormant haematopoietic stem cells in vivo. Nature 2009, 458, 904-908. [CrossRef] [PubMed]

59. Zhang, Y.; Jones, M.; McCabe, A.; Winslow, G.M.; Avram, D.; MacNamara, K.C. MyD88 signaling in CD4 T cells promotes IFN- $\gamma$ production and hematopoietic progenitor cell expansion in response to intracellular bacterial infection. J. Immunol. 2013, 190, 4725-4735. [CrossRef] [PubMed]

60. Heidt, T.; Sager, H.B.; Courties, G.; Dutta, P.; Iwamoto, Y.; Zaltsman, A.; von Zur Muhlen, C.; Bode, C.; Fricchione, G.L.; Denninger, J.; et al. Chronic variable stress activates hematopoietic stem cells. Nat. Med. 2014, 20, 754-758. [CrossRef] [PubMed]

61. Dutta, P.; Sager, H.B.; Stengel, K.R.; Naxerova, K.; Courties, G.; Saez, B.; Silberstein, L.; Heidt, T.; Sebas, M.; Sun, Y.; et al. Myocardial Infarction Activates CCR2 ${ }^{+}$Hematopoietic Stem and Progenitor Cells. Cell Stem Cell 2015, 16, 477-487. [CrossRef] [PubMed]

62. Yvan-Charvet, L.; Pagler, T.; Gautier, E.L.; Avagyan, S.; Siry, R.L.; Han, S.; Welch, C.L.; Wang, N.; Randolph, G.J.; Snoeck, H.W.; et al. ATP-binding cassette transporters and HDL suppress hematopoietic stem cell proliferation. Science 2010, 328, 1689-1693. [CrossRef] [PubMed]

63. Guerriero, A.; Worford, L.; Holland, H.K.; Guo, G.R.; Sheehan, K.; Waller, E.K. Thrombopoietin is synthesized by bone marrow stromal cells. Blood 1997, 90, 3444-3455. [PubMed]

64. Petzer, A.L.; Zandstra, P.W.; Piret, J.M.; Eaves, C.J. Differential cytokine effects on primitive (CD34+CD38-) human hematopoietic cells: Novel responses to Flt3-ligand and thrombopoietin. J. Exp. Med. 1996, 183, 2551-2558. [CrossRef] [PubMed]

65. Taichman, R.S.; Emerson, S.G. Human osteoblasts support hematopoiesis through the production of granulocyte colony-stimulating factor. J. Exp. Med. 1994, 179, 1677-1682. [CrossRef] [PubMed]

66. Sutherland, H.J.; Eaves, C.J.; Lansdorp, P.M.; Thacker, J.D.; Hogge, D.E. Differential regulation of primitive human hematopoietic cells in long-term cultures maintained on genetically engineered murine stromal cells. Blood 1991, 78, 666-672. [PubMed]

67. Doan, P.L.; Russell, J.L.; Himburg, H.A.; Helms, K.; Harris, J.R.; Lucas, J.; Holshausen, K.C.; Meadows, S.K.; Daher, P.; Jeffords, L.B.; et al. Tie ${ }^{+}$bone marrow endothelial cells regulate hematopoietic stem cell regeneration following radiation injury. Stem Cells 2013, 31, 327-337. [CrossRef] [PubMed]

68. Salter, A.B.; Meadows, S.K.; Muramoto, G.G.; Himburg, H.; Doan, P.; Daher, P.; Russell, L.; Chen, B.; Chao, N.J.; Chute, J.P. Endothelial progenitor cell infusion induces hematopoietic stem cell reconstitution in vivo. Blood 2009, 113, 2104-2107. [CrossRef] [PubMed]

69. Zheng, J.; Huynh, H.; Umikawa, M.; Silvany, R.; Zhang, C.C. Angiopoietin-like protein 3 supports the activity of hematopoietic stem cells in the bone marrow niche. Blood 2011, 117, 470-479. [CrossRef] [PubMed]

70. Hooper, A.T.; Butler, J.M.; Nolan, D.J.; Kranz, A.; Iida, K.; Kobayashi, M.; Kopp, H.G.; Shido, K.; Petit, I.; Yanger, K.; et al. Engraftment and reconstitution of hematopoiesis is dependent on VEGFR2-mediated regeneration of sinusoidal endothelial cells. Cell Stem Cell 2009, 4, 263-274. [CrossRef] [PubMed]

71. Ellis, R.J. Protein folding: Inside the cage. Nature 2006, 442, 360-362. [CrossRef] [PubMed]

72. Asada, N.; Katayama, Y.; Sato, M.; Minagawa, K.; Wakahashi, K.; Kawano, H.; Kawano, Y.; Sada, A.; Ikeda, K.; Matsui, T.; et al. Matrix-embedded osteocytes regulate mobilization of hematopoietic stem/progenitor cells. Cell Stem Cell 2013, 12, 737-747. [CrossRef] [PubMed] 
73. Greenbaum, A.; Hsu, Y.M.; Day, R.B.; Schuettpelz, L.G.; Christopher, M.J.; Borgerding, J.N.; Nagasawa, T.; Link, D.C. CXCL12 in early mesenchymal progenitors is required for haematopoietic stem-cell maintenance. Nature 2013, 495, 227-230. [CrossRef] [PubMed]

74. Ludin, A.; Gur-Cohen, S.; Golan, K.; Kaufmann, K.B.; Itkin, T.; Medaglia, C.; Lu, X.J.; Ledergor, G.; Kollet, O.; Lapidot, T. Reactive oxygen species regulate hematopoietic stem cell self-renewal, migration and development, as well as their bone marrow microenvironment. Antioxid. Redox Signal. 2014, 21, 1605-1619. [CrossRef] [PubMed]

75. Miyamoto, K.; Araki, K.Y.; Naka, K.; Arai, F.; Takubo, K.; Yamazaki, S.; Matsuoka, S.; Miyamoto, T.; Ito, K.; Ohmura, M.; et al. Foxo3a is essential for maintenance of the hematopoietic stem cell pool. Cell Stem Cell 2007, 1, 101-112. [CrossRef] [PubMed]

76. Juntilla, M.M.; Patil, V.D.; Calamito, M.; Joshi, R.P.; Birnbaum, M.J.; Koretzky, G.A. AKT1 and AKT2 maintain hematopoietic stem cell function by regulating reactive oxygen species. Blood 2010, 115, 4030-4038. [CrossRef] [PubMed]

77. Ito, K.; Hirao, A.; Arai, F.; Matsuoka, S.; Takubo, K.; Hamaguchi, I.; Nomiyama, K.; Hosokawa, K.; Sakurada, K.; Nakagata, N.; et al. Regulation of oxidative stress by ATM is required for self-renewal of haematopoietic stem cells. Nature 2004, 431, 997-1002. [CrossRef] [PubMed]

78. Massberg, S.; Schaerli, P.; Knezevic-Maramica, I.; Kollnberger, M.; Tubo, N.; Moseman, E.A.; Huff, I.V.; Junt, T.; Wagers, A.J.; Mazo, I.B.; et al. Immunosurveillance by hematopoietic progenitor cells trafficking through blood, lymph, and peripheral tissues. Cell 2007, 131, 994-1008. [CrossRef] [PubMed]

79. Murphy, A.J.; Bijl, N.; Yvan-Charvet, L.; Welch, C.B.; Bhagwat, N.; Reheman, A.; Wang, Y.; Shaw, J.A.; Levine, R.L.; Ni, H.; et al. Cholesterol efflux in megakaryocyte progenitors suppresses platelet production and thrombocytosis. Nat. Med. 2013, 19, 586-594. [CrossRef] [PubMed]

80. Singh, R.B.; Mengi, S.A.; Xu, Y.J.; Arneja, A.S.; Dhalla, N.S. Pathogenesis of atherosclerosis: A multifactorial process. Exp. Clin. Cardiol. 2002, 7, 40-53. [PubMed]

81. Gomes, A.L.; Carvalho, T.; Serpa, J.; Torre, C.; Dias, S. Hypercholesterolemia promotes bone marrow cell mobilization by perturbing the SDF-1:CXCR4 axis. Blood 2010, 115, 3886-3894. [CrossRef] [PubMed]

82. Westerterp, M.; Gourion-Arsiquaud, S.; Murphy, A.J.; Shih, A.; Cremers, S.; Levine, R.L.; Tall, A.R.; Yvan-Charvet, L. Regulation of hematopoietic stem and progenitor cell mobilization by cholesterol efflux pathways. Cell Stem Cell 2012, 11, 195-206. [CrossRef] [PubMed]

83. Si, Y.; Tsou, C.L.; Croft, K.; Charo, I.F. CCR2 mediates hematopoietic stem and progenitor cell trafficking to sites of inflammation in mice. J. Clin. Investig. 2010, 120, 1192-1203. [CrossRef] [PubMed]

84. Wang, X.; Gao, M.; Schouteden, S.; Roebroek, A.; Eggermont, K.; van Veldhoven, P.P.; Liu, G.; Peters, T.; Scharffetter-Kochanek, K.; Verfaillie, C.M.; et al. Hematopoietic stem/progenitor cells directly contribute to arteriosclerotic progression via integrin $\beta 2$. Stem Cells 2015, 33, 1230-1240. [CrossRef] [PubMed]

85. Gordon, D.J.; Probstfield, J.L.; Garrison, R.J.; Neaton, J.D.; Castelli, W.P.; Knoke, J.D.; Jacobs, D.R., Jr.; Bangdiwala, S.; Tyroler, H.A. High-density lipoprotein cholesterol and cardiovascular disease. Four prospective American studies. Circulation 1989, 79, 8-15. [CrossRef] [PubMed]

86. Rosenson, R.S.; Brewer, H.B., Jr.; Davidson, W.S.; Fayad, Z.A.; Fuster, V.; Goldstein, J.; Hellerstein, M.; Jiang, X.C.; Phillips, M.C.; Rader, D.J.; et al. Cholesterol efflux and atheroprotection: Advancing the concept of reverse cholesterol transport. Circulation 2012, 125, 1905-1919. [CrossRef] [PubMed]

87. Kratzer, A.; Giral, H.; Landmesser, U. High-density lipoproteins as modulators of endothelial cell functions: Alterations in patients with coronary artery disease. Cardiovasc. Res. 2014, 103, 350-361. [CrossRef] [PubMed]

88. Khan, R.; Spagnoli, V.; Tardif, J.C.; L'Allier, P.L. Novel anti-inflammatory therapies for the treatment of atherosclerosis. Atherosclerosis 2015, 240, 497-509. [CrossRef] [PubMed]

89. Patel, S.; Drew, B.G.; Nakhla, S.; Duffy, S.J.; Murphy, A.J.; Barter, P.J.; Rye, K.A.; Chin-Dusting, J.; Hoang, A.; Sviridov, D.; et al. Reconstituted high-density lipoprotein increases plasma high-density lipoprotein anti-inflammatory properties and cholesterol efflux capacity in patients with type 2 diabetes. J. Am. Coll. Cardiol. 2009, 53, 962-971. [CrossRef] [PubMed]

90. Tolani, S.; Pagler, T.A.; Murphy, A.J.; Bochem, A.E.; Abramowicz, S.; Welch, C.; Nagareddy, P.R.; Holleran, S.; Hovingh, G.K.; Kuivenhoven, J.A.; et al. Hypercholesterolemia and reduced HDL-C promote hematopoietic stem cell proliferation and monocytosis: Studies in mice and FH children. Atherosclerosis 2013, 229, 79-85. [CrossRef] [PubMed] 
91. Schmidt, M.I.; Duncan, B.B.; Sharrett, A.R.; Lindberg, G.; Savage, P.J.; Offenbacher, S.; Azambuja, M.I.; Tracy, R.P.; Heiss, G. Markers of inflammation and prediction of diabetes mellitus in adults (Atherosclerosis Risk in Communities study): A cohort study. Lancet 1999, 353, 1649-1652. [CrossRef]

92. Schipper, H.S.; Nuboer, R.; Prop, S.; van den Ham, H.J.; de Boer, F.K.; Kesmir, C.; Mombers, I.M.; van Bekkum, K.A.; Woudstra, J.; Kieft, J.H.; et al. Systemic inflammation in childhood obesity: Circulating inflammatory mediators and activated $\mathrm{CD}_{14}^{++}$monocytes. Diabetologia 2012, 55, 2800-2810. [CrossRef] [PubMed]

93. Nagareddy, P.R.; Murphy, A.J.; Stirzaker, R.A.; Hu, Y.; Yu, S.; Miller, R.G.; Ramkhelawon, B.; Distel, E.; Westerterp, M.; Huang, L.S.; et al. Hyperglycemia promotes myelopoiesis and impairs the resolution of atherosclerosis. Cell Metab. 2013, 17, 695-708. [CrossRef] [PubMed]

94. Nagareddy, P.R.; Kraakman, M.; Masters, S.L.; Stirzaker, R.A.; Gorman, D.J.; Grant, R.W.; Dragoljevic, D.; Hong, E.S.; Abdel-Latif, A.; Smyth, S.S.; et al. Adipose tissue macrophages promote myelopoiesis and monocytosis in obesity. Cell Metab. 2014, 19, 821-835. [CrossRef] [PubMed]

95. Ridker, P.M. From C-Reactive Protein to Interleukin-6 to Interleukin-1: Moving Upstream To Identify Novel Targets for Atheroprotection. Circ. Res. 2016, 118, 145-156. [CrossRef] [PubMed]

96. Brown, W.V.; Remaley, A.T.; Ridker, P.M. JCL Roundtable: Is inflammation a future target in preventing arteriosclerotic cardiovascular disease. J. Clin. Lipidol. 2015, 9, 119-128. [CrossRef] [PubMed]

(c) 2016 by the authors; licensee MDPI, Basel, Switzerland. This article is an open access article distributed under the terms and conditions of the Creative Commons Attribution (CC-BY) license (http:/ / creativecommons.org/licenses/by/4.0/). 